\title{
Visible pulsus parvus et tardus in patient of aortic stenosis
}

\author{
Pawan Kumar Singh, Gauri Jangpangi
}

Pulmonary Medicine, Post Graduate Institute of Medical Education and Research, Chandigarh, India

\section{Correspondence to} Dr Pawan Kumar Singh, ga.ps. complete@gmail.com

Accepted 23 May 2017

\section{CrossMark}

\section{To cite: Singh PK} Jangpangi G. BMJ Case Rep Published Online First: [please include Day Month Year]. doi:10.1136/bcr-2017221034

\section{DESCRIPTION}

A 35-year-old male presenting with 1-year history of shortness of breath and angina on exertion. On examination, he was noted to have pulsatile neck vessels and ejection systolic murmur as shown in video 1. Possibilities kept for pulsatile neck vessels were aortic regurgitation (AR; dancing carotid), tricuspid regurgitation (TR; c-v waves), third-degree heart block (canon a wave) and thoracic aortic aneurysm. Two-dimensional (2D) echocardiography was done which ruled out any AR, TR lesions and showed presence of severe aortic stenosis in four-chamber view video 2 with severity confirmed in Doppler parasternal long-axis view video 3.

Pulsus parvus et tardus is a palpatory finding of AS. Here, we have met an unusual cause of pulsatile neck vessels, that is, murmur of AS being transmitted to neck in manner that it becomes visible making it 'visible' pulsus parvus et tardus. Video 1 shows the slow rising and late peaking pulse seen

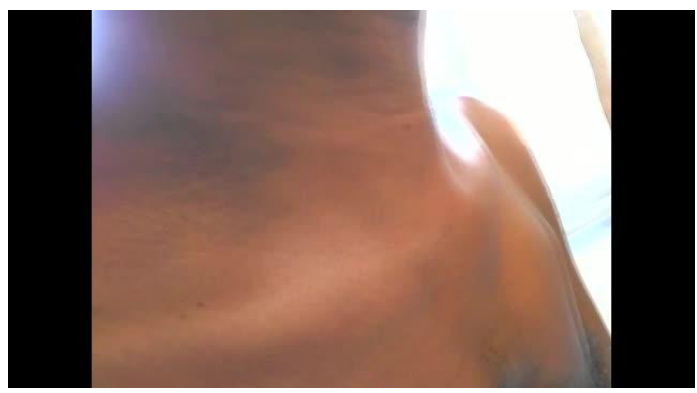

Video 1 Showing regularly pulsating neck vessels with highest impact in suprasternal notch and radiating to lateral as well as superior aspect.

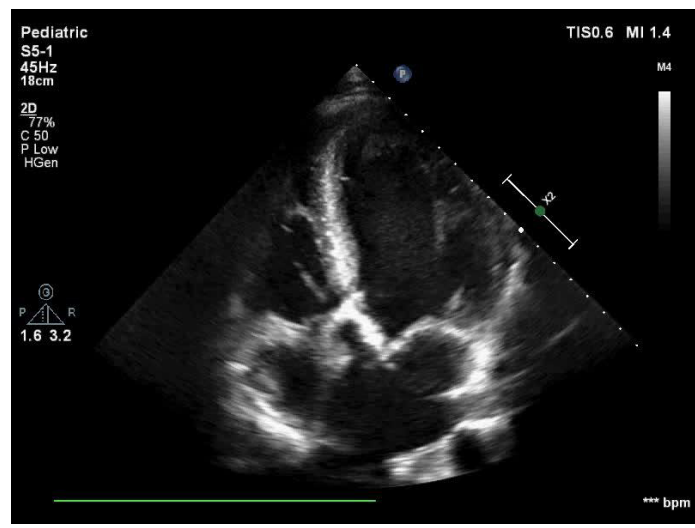

Video 2 Apical five-chamber view showing dilated and hypertrophied left ventricular cavity and dilated left atrial cavity, also showing thickened and calcified aortic valve with severe restriction of valve mobility.

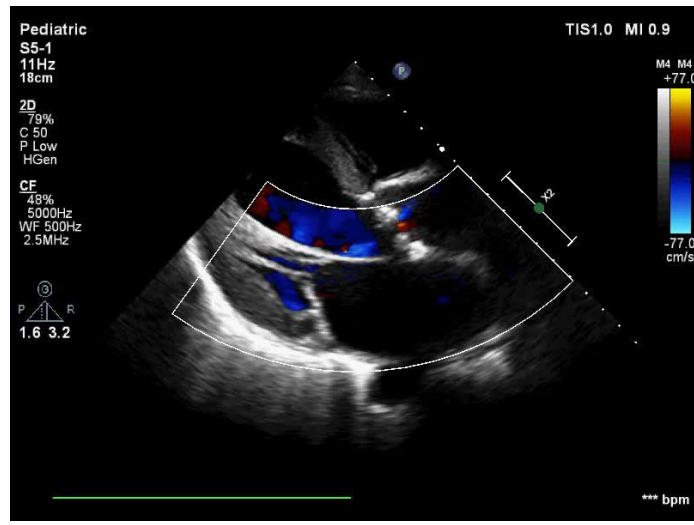

Video 3 Parasternal long-axis view with colour Doppler showing thickened and calcified aortic valve leaflets with restricted mobility and flow acceleration noted across the aortic valve suggestive of severe aortic stenosis.

\section{Learning points}

- Pulsatile neck vessels following a specific pattern can help to narrow down the differentials.

- Differentiation between jugular venous pressure (JVP) and carotid pulsations is of paramount importance.

- Visible as well as palpable pulsatile pulsus parvus et tardus still has a clinical relevance in the era of echocardiography.

in suprasternal notch that coincides with the ejection systolic murmur of aortic valve stenosis along with corresponding 2D echocardiographic images (videos 2 and 3).

Contributors Both authors had seen and evaluated this patient History taking and physical examination was done by each of the two authors individually. Our patient, a daily wager and kind gentleman, was nice enough for contributing to the writing of this report by agreeing to consent for the video filming and later agreeing to get this work submitted for publication. Ground root level work of getting this video filmed was done by GJ, and the idea of sharing this experience with the world, writing it and publishing it was of PKS. Both of the authors take full and equal responsibility of this work and its authenticity, but PKS will be the guarantor for this project. Both authors have read this report and are in full agreement of its contents.

Competing interests None declared.

Patient consent Obtained.

Provenance and peer review Not commissioned; externally peer reviewed.

(C) BMJ Publishing Group Ltd (unless otherwise stated in the text of the article) 2017. All rights reserved. No commercial use is permitted unless otherwise expressly granted. 
Copyright 2017 BMJ Publishing Group. All rights reserved. For permission to reuse any of this content visit http://group.bmj.com/group/rights-licensing/permissions.

BMJ Case Report Fellows may re-use this article for personal use and teaching without any further permission.

Become a Fellow of BMJ Case Reports today and you can:

- Submit as many cases as you like

- Enjoy fast sympathetic peer review and rapid publication of accepted articles

Access all the published articles

Re-use any of the published material for personal use and teaching without further permission

For information on Institutional Fellowships contact consortiasales@bmjgroup.com

Visit casereports.bmj.com for more articles like this and to become a Fellow 